\title{
Nebojša Jovanović
}

\section{Zazor od modernosti:}

Trauma '68. i 'sudar civilizacijâ’ u djelu
Živojina Pavlovića

Kriza i kritike racionalnosti. Nasljeđe '68.

Ur. B. Mikulić/M. Žitko, Zagreb: Filozofski fakultet 2019. 


\section{SAŽETAK}

U Živojinu Pavloviću, uglednom jugoslavenskom piscu i reditelju, današnja post-jugoslavenska kritička teorija u pravilu vidi mislioca koji je detektirao ideološka i društvena proturječja socijalističke Jugoslavije, posebno ona koja su nadživjela tu državu i metastazirala u periodu "tranzicije". No izvan te recepcije ostaju proturječja i mrtvouzice koja prožimaju sam Pavlovićev rad i svjetonazor. Tvrdeći da neke od tih mrtvouzica ukazuju na Pavlovićev snažan antimoderni (antipolitički, antifeministički) impuls, ovaj tekst ih ilustrira njegovom "teorijom" o sukobu "kristalnih" i "amorfnih" civilizacija, koju je uobličio u vrijeme raspada SFRJ. Pri tome ću se fokusirati na Pavlovićeva razmišljanja o trima temama koja ga prikazuju u njegovom najreakcionarnijem ("ničeanskom") izdanju: o razgradnji Jugoslavije kroz nacionalizam i rat, o spolu i rodu (napose o "ženstvu”), te o komunističkoj revoluciji. Želi li istinski aproprirati Pavlovićevu ostavštinu, postjugoslavenska lijeva kritička teorija ne bi smjela previdjeti ili potisnuti "kontrarevolucionarnu" i, u konačnoj analizi, depolitizirajuću liniju argumentacije koja dominira njegovim razmišljanjima. 


\section{Abhorrence of Modernity: \\ The '68 Trauma and 'The Clash of Civilisations' \\ in Živojin Pavlovičs Work}

\section{ABSTRACT}

Živojin Pavlović, a renowned Yugoslav author and film director, is usually lauded by the post-Yugoslav critical theory as an outstanding thinker who detected the ideological and social contradictions of socialist Yugoslavia, especially those that outlived the country and metastasized in the period of the post-socialist "transition". What remains unacknowledged by that contemporary account are the contradictions and deadlocks that suffuse Pavlovićs work and worldview. Arguing that some of those deadlocks testify to Pavlovićs strong antimodern (antipolitical, antifeminist) impulse, the article illustrates them on the example of his "theory" about the clash of "crystal" and "amorphous" civilizations, which he came up with during the disintegration of the socialist Yugoslavia. I focus on Pavlovićs musings about the three topics that expose him in his most reactionary ("Nietzschean") attitudes. Those topics are: the dissolution of Yugoslavia by means of nationalist ideology and war, sex and gender (especially the problem of "womanhood"), and communist revolution. If the post-Yugoslav left theory truly wants to appropriate Pavlovićs legacy, it should not overlook or repress the "counterrevolutionary" and, ultimately, depoliticizing streak of arguments that dominates those musings. 


\section{Od napukle fasade do smaka svijeta}

Jugoslavenska '68. bila je po Živojinu Pavloviću “eksplozija na jednoj ogromnoj, davno nastaloj i stalno farbanoj i zafarbavanoj kartonskoj fasadi. Puklo je, pukotina je ostala i svi su svesni da ta fasada nije bila zid, nije građevina, nije velelepni dvorac, nego jedna lažna potemkinova kulisa” ${ }^{01}$ Reditelj i književnik koji je već tada bio poznat po intelektualnom stavu protiv dominantnih vrijednosti i ideala jugoslavenskog socijalizma, govorio je na osnovi neposrednog, osobnog iskustva 'lipanjskih gibanja'. Štoviše, njegovi dnevnički zapisi od 2. do 9. lipnja 1968., objavljeni pod naslovom Ispljuvak pun krvi (1990), ostaju najmarkatnije književno svjedočanstvo o tim događajima.

Sama činjenica da je prvo izdanje dnevnika sudski zabranjeno i uništeno 1984. godine pokazuje koliko je dugo Pavlovićevo viđenje studentskih protesta ostalo nepomirljivo s oficijelnim dogmama o suvremenoj jugoslavenskoj historiji. Knjiga nije zabranjena naprosto samo zbog dramatičnog opisa policijskog nasilja nad prosvjednicima, poput brutalnog sprečavanja studenata da iz Studentskog grada dođu u centar Beograda:

"Istog trenutka milicijske snage nasrću na studente. Pendreče ih zverski, po desetorica na jednog. One, koje obaraju na zemlju, tuku do nesvesti. [...] Najveća poniženja trpe devojke. Neispavane, ošamućene uzbuđenjem i sunčevom pripekom, sedele su po strani, $\mathrm{u}$ grupicama. Njih zapljuskuje najžešći bes organa reda. Provincijski milicioneri, podivljali od nesna i iskonske seljačke mržnje prema građanima, sa strašću kidišu na njihove frizure, na tanke, providne haljine i belo meso koje blešti ispod pokidane odeće. Tuku ih, gaze, cepaju im bluze i grudnjake, uzvikujući: 'Kurve!' Oni, koji pokušavaju da devojkama pruže zaštitu, ili da ih iznesu iz meteža, bivaju udarcima pendrekom obarani na zemlju. Pokolj traje nekoliko minuta." ${ }^{2}$

Ipak, iako dramatični, ovakvi opisi ne čine veći dio dnevnika, a erupcija nasilja se ionako mogla objasniti kao trenutačno iskakanje iz inače urednog sistema - milicija se tek malo zanijela, vjerovatno i sama zatečena i uplašena nesvakidašnjom situacijom, masom itd. Knjiga je zabranjena zbog nečeg drugog: Pavlović je u dnevniku prenio pismo koje je umirovljenik iz Zagreba Nikola Čučković poslao beogradskim

01 Živojin Pavlović, Đavolji film: Ogledi i razgovori, 266.

02 Živojin Pavlović, Ispljuvak pun krvi, 31-32. 
studentima u znak solidarnosti. Čučković je u pismu detaljno opisao svoje stradanje nakon raskola između Staljina i Tita 1948. godine, kada je kao IB-ovac uhapšen i osuđen prvo na godinu zatvora, a kasnije - nakon što je nakratko oslobođen slijedom vlastite žalbe - na sedam godina strogog zatvora, od čega je izdržao šest godina. On ne opisuje samo vlastitu torturu koju je prošao u kaznionicama od Novog Sada, preko Stare Gradiške, otoka Sv. Grgur i Ugljen, Bileće, do Golog otoka; detaljno je evidentirao i primjere drastičnog zlostavljanja i ubojstava, navodeći cijele spiskove isljednika i krvnika, kao i njihovih žrtava: "Nas su ubijali, prebijali, sakatili, mrcvarili, linčovali, izvrgavali ruglu, $[t]$ ukli su nas vezane, gladne, isprebijane, iznemogle, bolesne”. ${ }^{03}$ Pismo je zapravo mala kolekcija tekstova: tu su Čučkovićevi dopisi kojima je od tužilaštava Grada Zagreba, SR Hrvatske i FNRJ tražio da se sva ta mučenja i ubojstva istraže, a zločinci iz redova Udbe kazne. Štoviše, Čučković je o svemu tome prvo pisao Josipu Brozu Titu osobno, u lipnju 1966., neposredno nakon pada Aleksandra Rankovića, prvog čovjeka Udbe. Činilo mu se nemogućim i uzaludnim pozivati na suđenje "Rankovićevim dželatima" dok je njihov nalogodovac bio na vlasti. Iskustvo mu je pokazalo da pad Rankovića tu ništa nije promijenio: "[N]ajviši organi, čuvari zakona, čuvaju bezakonje". ${ }^{4}$

Pavlović je nepogrešivo prepoznao značaj Čučkovićevog pisma i objavio ga u cijelosti, sa svim prilozima: ono je bilo ključni dokaz da nasilje nad studentima nije bilo incident, ispad iz sistema, nego - sistem sâm. Kontinuitet sistemskog nasilja, koji Čučković prepoznaje od '48. do '68., savršeno ilustrira i Pavlovićev zazor prema socijalističkoj Jugoslaviji. Smatrao je da zna pravu istinu o njoj, da je prozreo kroz njezinu potemkinovsku fasadu koja je skrivala dogmatizam, korupciju, teror - ukratko, kulisu koju je trebalo raznijeti. "Biće skoro propast sveta - nek' propadne, nije šteta!”, pjevalo se u jednom jugoslavenskom filmu iz 1968. godine: iako ga Pavlović nije režirao, film je izražavao i njegov odium prema temeljnim ideološkim koordinatama tog svijeta. ${ }^{05}$ Uostalom, i naslov njegovog filma Nasvidenje v naslednji vojni / Doviđenja u sljedećem ratu (1980) sugerirao je isti samozadovoljni, ako ne i cinični stav o nestabilnosti i prolaznosti socijalističke modernosti.

Premotajmo sada film brzo naprijed, na kraj '8o-ih i početak' $90-i h$. Posljednja velika politička kriza u zemlji uistinu eskalira u "naslednju

03 Ibid., 174.

04 Ibid., 176.

05 Riječ je o filmu Aleksandra Petrovića, Biće skoro propast sveta (1968). 
vojnu”, a Pavlovićevu reakciju opet nalazimo u njegovoj dnevničkoj i memoarskoj prozi. I ovaj put ona je simptomatična, ali na značajno drugačiji način nego zapisi iz '68:

"Vreme iluzija i prividnog spokojstva smenjuju godine pljački, otimačina i krvavih obračuna; u njima ne stradaju anonimni akteri novog podzemlja izniklog na ratom opustošenoj zemlji, već nauka, obrazovanje, kultura, umetnost; s njima, vera u čoveka i njegovo dostojanstvo. Najednom, kao da je na Balkanu počeo smak sveta, takođe i kraj svih obmana i samoodbrana. Ugrožen i biološki i egzistencijalno, ljudski stvor, prepušten samoći a usred haotičnog meteža u kome gubi i najelementarniji identitet, iznenadno se suočava sa ogoljenom svojom obrazinom, pitajući se: Jesam li to zaista ja? I: Zar je moguće da je lice koje gledam toliko nakazno, da od njega okrećem glavu s najvećim gnušanjem, u želji da ne priznam da je to grozno, zastrašujuće lice - moje?"06

Krah sistema i države koje je cijeli život nemilosrdno napadao uzdrmali su Pavlovića snagom dubinske traume. Vrijednosti i norme jugoslavenskog socijalizma, od kojih je zazirao, odjednom su postale stvari koje treba braniti. Iako je u periodu socijalizma i dalje vidio "vreme iluzija i lažnog spokojstva”, sada nije bilo sumnje da je u njemu bilo i nečega osim iluzija i laži. ${ }^{07}$ Odnosno, tek nakon kraja socijalističke Jugoslavije, Pavlović kao da je shvatio da je ona ipak bila država živih - nasuprot postjugoslavenskoj Državi mrtvih, kako je naslovio svoj film o "tranziciji”, ${ }^{08}$ periodu u kome je zanijekano sâmo ljudsko dostojanstvo, a znanost, obrazovanje i kultura gube neupitni značaj koje su imale u socijalizmu. To što je sebe vidio kao nekoga tko nije nasjeo na socijalističke laži o emancipaciji i napretku, Pavlović je na koncu platio traumatičnim doživljajem 'smaka svijeta' i slomom subjektiviteta: 'To grozno, gnusno ogoljeno lice — zar sam to zaista ja!?’09

06 Živojin Pavlović, Planeta filma: Sećanja, 250.

07 Otud i često citirana Pavlovićeva tvrdnja da će period Titove vladavine, iako totalitaran i represivan, $\mathrm{u}$ historiji jugoslavenskih naroda ipak ostati upisan kao Periklovo doba. Vidi Mirko Kovač (2006), "Kao svinje u blatu”, 462.

08 I sâm Pavlović umro je u jeku "tranzicije”, 1998. godine, tokom snimanja Države mrtvih. Njegov je posao dovršio Dinko Tucaković te je film bio završen 2002. godine.

09 Ako ovaj preobražaj iz samozadovoljnog kritičara u zatečenog, šokiranog promatrača može zvučati paradoksalno, dovoljno je sjetiti se Lacanove 
Odgovoriti na to pitanje, značilo je sagledati svijet u novoj optici i iznova mu dati smisao. Štoviše, Pavloviću se činilo da izvanredne dimenzije kaosa zahtijevaju i izvanrednu, obuhvatnu analizu koja će odgovoriti na enigmu krvavog kraja jugoslavenskog socijalizma, i to u širem, globalnom kontekstu:

"Uzavrelog mozga, u čijim vijugama bolno varniče rojevi sukobljenih pitanja zaslepljujući me haotičnim odgovorima, pokušavam, izmičući se, u sebi, od svakodnevice, da se isčupam iz živog blata, stupim na čvrsto tlo i sagledam osnovne obrise ne samo lokalnih događaja, već i novih, nejasnih i zbunjujućih prilika na čitavom glôbu."

Krajem 1992. godine ta su Pavlovićeva nastojanja porodila knjigu Ludilo u ogledalu, koju je supotpisao s Dušankom Milanović-Zeković, novinarkom koja je s njim vodila niz razgovora od kolovoza do listopada 1991. godine. Tom je prilikom Pavlović objasnio kraj jugoslavenskog socijalizma i razgradnju države pomoću teze o sukobu dvaju suprotstavljenih civilizacijskih modela. Ta poanta i vrijeme objavljivanja knjige mogu nas navesti da se zapitamo je li Pavlović plagirao notorni The Clash of Civilisations, tezu Samuela Huntingtona koja se pojavila nekako istovremeno. ${ }^{11}$ Moguću nedoumicu otklanja i elementarna kronologija. Pavlović je svoju tezu po prvi put ekstenzivno predstavio 1989. godine, u knjizi Flogiston kao i u svojim dnevnicima gdje je učestalo elaborira tokom 1991. godine, paralelno s eskalacijom političke krize i rata. Štoviše, pretpostavku o suprostavljenim civilizacijama uživanja i civilizacijama nužnosti nalazimo još krajem ' 70 -ih: u opsežnom intervjuu koji je 1979. godine dao Nebojši Pajkiću, Nenadu Polimcu i Slobodanu Šijanu, govoreći o erotici i seksu, primjećuje da "mi [ljudi], a na tom počivaju i civilizacije, svaku svoju nužnost preobraćamo u zadovoljstvo". ${ }^{12}$

dosjetke "oni ne-prevareni se varaju" (les non-dupes errent). Ostanemo li u lacanovskom žargonu, možemo reći da Pavlović nije na vrijeme prepoznao izbor "le père ou pire" ["otac (tj. simbolički poredak) ili ono gore”]. Potcijenio je važnost "fasade” ili Simboličkog, a kada se ona potpuno sasula, iza nje se nije ukazala nikakva istina, nego sirova, ratna, post-apokaliptična "pustinja Realnog”- carstvo psihoze.

10 Pavlović (2002), Planeta filma, 250-251.

11 Konferencijsko predavanje 1992. godine, publicirano kao tekst 1993.

12 Nebojša Pajkić (ur.), Jahač na lokomotivi: Razgovori sa Živojinom Pavlovićem, 108. 
Do kraja '8o-ih Pavlović će ova dva civilizacijska modela (obilje i uživanje naspram primitivne civilizacije nužnosti) imenovati kristalnim i amorfnim civilizacijama; ti označitelji čine lakanovski "prošivni bod" (point de capiton) koji njegovu tezu definitivno razlikuje od Huntingtonove. Dok Huntingtonove "civilizacije" funkcioniraju prije i poslije svega u sferi geopolitike, Pavlovićeve pokušavaju definirati perenijalne ravni ljudskog postojanja. Već podnaslov knjige - Razgovori o civilizacijama, o religijama, o čoveku, o životu i smrti, o mržnji, o ljubavi - upućuje da je u pitanju svojevrsni antropozofski projekt.

Vrlo dobro svjestan kako njegov pothvat može izgledati, Pavlović sugerira da i sâm ima određenu distancu prema njemu. U jednu ruku, njime je htio što sistematičnije preispitati raspad Jugoslavije i postjugoslavenske ratove. Jedan od citata koji je moto knjige, a koji srećemo i u Pavlovićevim dnevnicima, pripada Williamu Blakeu: "Moram stvoriti sistem ili biti porobljen od tuđeg" ("I must create a system or be enslaved by another mans"). No, dok priziva sistem, Pavlović ga istodobno i odbacuje. Tvrdi da je u dramatičnim uvjetima "bezumlja kome se predajemo poput stoke na klanici [...] neprimereno bilo kakvo sistematizovanje nahrupelih ideja ili nadobudno obrazovanje 'misaonog sistema' za kim čeznu tzv. filosofski umovi”. ${ }^{13}$ Štoviše, odbacuje sam medij pisane riječi kao krajnje nepodesan za refleksiju o "smaku sveta" i tvrdi da je (raz)govor "najpodesnija ambalaža za rasplamsale misli”. ${ }^{14}$ Iako ovo distanciranje od sistema i pisanja može izgledati kao Pavlovićev kritički meta-komentar vlastitog pothvata, ono sjajno ilustrira Lacanov diktum da "nema meta-jezika": i sama ta distanca opet pada u okvir civilizacijske razlike, jer sistem i pisana riječ ostaju obilježja kristalne civilizacije, dok je govor na strani amorfije.

Teza ovog rada je da vrijednost Pavlovićevih razmatranja o civilizacijama doista ne trebamo tražiti u registru filozofije nego fantazije. Na prvi pogled, imamo posla sa Pavlovićevom središnjom enigmom: kako to da je filmski i književni autor, cijenjen upravo zbog svog brutalnog i kritičkog pristupa društvenoj stvarnosti socijalizma, završio u potpunoj fantazmagoriji kada se susreo s njezinim kolapsom? Osobno bih odbacio logiku uzroka i posljedice koju to pitanje pretpostavlja. Predlažem da taj paradoks ne čitamo kao zagonetku nego kao

13 Živojin Pavlović i Dušanka Milanović-Zeković, Ludilo u ogledalu:

Razgovori o civilizacijama, o religijama, o čoveku, o životu i smrti, o mržnji, o ljubavi, 152.

14 Ibid. 
antagonizam koji nam omogućava da ponudimo nove interpretacije Pavlovićevog opusa.

\section{Kristal i amorfija}

Gledajući nekom prilikom na TV-u film Poltergeist Tobea Hoopera iz 1982., Pavlović je primijetio kako već njegov prvi kadar (panorama američkog gradića) sadrži “dominantnu pravu liniju i oštar ugao” te da je općenito komponiran tako da je "tipično uglađen, da ništa iz njega ne štrči, da je svet čvrsto užljebljen u četiri strane tog pravougaonika" ${ }^{15}$ Tada se sjetio "naših, ruskih, grčkih, turskih, gruzijskih, indijskih filmova”, u kojima kadrovi nisu komponirani kao u Poltergeistu, odnosno u američkim i većini evropskih filmova. Za Pavlovića je ovaj uvid imao epifanijski učinak:

"I, odjednom, počinju da mi se otvaraju pitanja: zašto je to tako? I vrlo brzo dolazim do ideje da se podele ne mogu praviti na klasičan način. Da su potpuno besmislene one postavke o podeli sveta na Sever-Jug, Istok-Zapad, ili, kapitalizam-socijalizam, razvijeni-nerazvijeni svet. Nego da se civilizacije dele na dva bloka u kojima dominiraju dve energije, a da se iz tih energija rađaju dva vizuelna profila." ${ }^{16}$

Ne vjerujem da ovdje trebamo trošiti prostor na detaljniju analizu Pavlovićeve generalizacije kojom je jednu rutinsku Spielbergovu produkciju ekspresno prometnuo u paradigmu američke i zapadnoevropske kinematografije. Citirani ulomak je zanimljiviji kao prečica za samu jezgru Pavlovićeve fantazije. Naime, energija koju spominje i na kojoj temelji svoje civilizacijske modele psihička je energija kolektivnog nesvjesnog, koja se navodno javlja u dva tipa-paranoidnom i šizofrenom. Paranoidno kolektivno nesvjesno odlikuje, prema Pavloviću, centripetalna psihička energija koja "sve usmerava ka cilju koji mora biti jasan, bespogovoran i usmeren ka večnosti. [...] plodove ovakvih energija krštavam civilizacijom kristala. Kristal je simbol nečeg što je večno, lepo, što je nepromenljivo, a pri tom hladno"; specifičnosti ove civilizacije su i prava linija i pravolinijsko poimanje života - to "da se rađamo pa putujemo do smrti, znači prava linija od A ka B”. ${ }^{17}$

15 Pavlović i Milanović-Zeković, 15.

16 Ibid.

17 Ibid., 16. 
Nasuprot tome, šizofreno kolektivno nesvjesno odlikuje se centrifugalnom psihičkom energijom koja "sve oko sebe seje, rasipa i razbacuje, te je svet u proticanju, u mešanju, u turbulenciji [...]. I odsjaj tog stanja u civilizacijskom smislu jeste amorfna forma koja nema kad od silnih kretanja i proticanja da se svede na jedno, a to jedno da se pokaže kao večno". "Vizualni simboli ove civilizacije su jaje, odnosno krug i kružno kretanje kao simboli života i postojanja. Dok civilizacije kristala određuje imperativ vječnosti, amorfne civilizacije određuje imperativ trajanja.

Šizofrenu i paranoidnu psihičku energiju, kao i dva civilizacijska modela, Pavlović kontrastira kao dva pola. ${ }^{19} \mathrm{~S}$ obzirom da je tu polarnost Pavlović opisao kroz cijeli niz razlika između amorfne i kristalne civilizacije, ovdje ih sažimam radi ekonomičnosti i preglednosti:

\begin{tabular}{|l|l|}
\hline AMORFNE CIVILIZACIJE & KRISTALNE CIVILIZACIJE \\
\hline $\begin{array}{l}\text { Prevlast šizofrenije u kolektivnom } \\
\text { nesvjesnom (“bolest rastočenog, } \\
\text { raspadnutog uma”) }\end{array}$ & $\begin{array}{l}\text { Prevlast paranoje u kolektivnom } \\
\text { nesvjesnom (“bolest izoštrenog, } \\
\text { kreativnog, nepoverljivog uma”) }\end{array}$ \\
\hline Centrifugalne psihičke sile & Centripetalne psihičke sile \\
\hline Primat kolektivnog & Primat individualnog \\
\hline Istok & Zapad \\
\hline Selo & Grad \\
\hline Primarno, primordijalno & Sekundarno, rafinirano \\
\hline Dionizijsko & Apolonijsko \\
\hline Horizontalno & Vertikalno \\
\hline Crvena, crna, žuta rasa & Bijela rasa \\
\hline Nužnost & Ugoda \\
\hline Religija & Politika \\
\hline
\end{tabular}

18 Ibid.

19 Pavlović koristi zakučaste sintagme, poput "polarizacija kolektivnog nesvesnog oko stožera šizofrene prirode" i sl. Općenito, njegov svjetonazor preferira polarnost kao neku vrstu univerzalnog ili dominantnog načela: "Podela na dva pola postoji i u biologiji, postoji i u drugim oblastima, u astronomiji, geografiji i geologiji na primer [...]" (ibid., 19-20). 


\begin{tabular}{|l|l|}
\hline $\begin{array}{l}\text { Ritual, statičnost, } \\
\text { letargija }\end{array}$ & $\begin{array}{l}\text { Organizacija, dinamičnost, } \\
\text { progres }\end{array}$ \\
\hline Kriva linija; krug & Ravna linija; oštar ugao \\
\hline Oblutak (kamen-lopta); jaje; kugla & Dijamant; piramida; neboder \\
\hline $\begin{array}{l}\text { Promjena; trajanje; } \\
\text { pečat života }\end{array}$ & $\begin{array}{l}\text { Definitivnost; vječnost; } \\
\text { pečat smrti }\end{array}$ \\
\hline $\begin{array}{l}\text { Misticizam; mudrost; } \\
\text { zaumnost i iracionalnost }\end{array}$ & $\begin{array}{l}\text { Veliki filozofski sistemi; } \\
\text { znanost; racionalost }\end{array}$ \\
\hline $\begin{array}{l}\text { Filosofija prolaznosti; odsustvo } \\
\text { filosofije }\end{array}$ & Filosofija vječnosti \\
\hline Univerzalnost, cjelovitost & Partikularnost, fragmentarnost \\
\hline Govorni iskaz & Pisana riječ \\
\hline $\begin{array}{l}\text { Pravoslavlje, } \\
\text { nekršćanske religije }\end{array}$ & $\begin{array}{l}\text { Svi tipovi kršćanstva osim } \\
\text { ortodoksnog }\end{array}$ \\
\hline Uživanje u duhovnom & Uživanje u fizičkom \\
\hline Komunističke revolucije & Fašističke revolucije \\
\hline Žensko načelo & Muško načelo \\
\hline $\begin{array}{l}\text { Ratovi kao reakcija na osjećanje } \\
\text { besmislenosti života }\end{array}$ & $\begin{array}{l}\text { Suicid kao reakcija na osjećanje } \\
\text { besmislenosti života }\end{array}$ \\
\hline Umjetnici kao tvorci & Umjetnici kao izvođači \\
\hline
\end{tabular}

U daljnjem tekstu neću prolaziti kroz sve ove parove polarnih suprotnosti nego ću se fokusirati na to kako neke od njih funkcioniraju u Pavlovićevim pogledima na specifične teme. Ali, prije toga želim istaknuti ono što vidim kao glavne, opće probleme s Pavlovićevom tezom. Prije svega, ona je svojevrsna "krparija" raznih filozofskih i književnih autora. Strukturno gledano, ne iznenađuje da je Pavlovićev Flogiston - prva knjiga u kojoj ekstenzivno iznosi svoju tezu — zapravo scrapbook, kolaž citata drugih autora i vlastitih zabilježaka. Rečeno riječima s unutrašnje strane korica, to je "hibrid, spoj eseja, sentenci, narativnih skica, zapisa i anegdota sa ispisima iz 'dnevnika čitaoca”. Među filosofskim utjecajima posebno se izdvaja Nietzsche, koga je Pavlović čitao zdravorazumski, takoreći na prvu loptu. Tako je, na primjer, cijela dihotomija između kristalnog i amorfnog načela svojevrsna varijacija podjele na apolonijsko i dionizijsko. 
Drugo, Pavlović privilegira jedan civilizacijski model kao superioran. Imamo li u vidu njegov fetiš Nietzschea, nema mjesta čuđenju da su Pavlovićeve simpatije i identifikacija na strani dionizijske amorfije. Kristalna civilizacija Zapada, na primjer, ulaže mnogo napora, resursa i znanja u osvajanje svemira i slične znanstvene pothvate, ali sa stajališta amorfne civilizacije, postavlja se pitanje: Čemu sve to? Iz perspektive religije, mudrosti i mita - tih za Pavlovića egzemplarnih modela spoznaje u amorfiji — znanstveni i tehnološki napredak, fundamentalno ne mijenja ljudsko stanje nego postaje sam sebi svrha. Taj sukob svjetonazorâ, u kome amorfija odnosi konačnu pobjedu pozivajući se na uzaludnost i besmisao ljudskog postojanja, ne odlikuje samo najsofisticiranije domete ljudskog stvaralaštva nego i najbanalniju svakodnevicu. Na primjer, kada bi amorfne civilizacije usvojile vrijednosti civilizacije kristala,

"normalno bi bilo da se [u njima] po parkovima i seoskim dvorištima glavačke prave betonske staze, i ne bi se vekovima i vekovima gacalo blato. I ne bi se sralo u kukuruzima nego u vaser-klozetima. Ali, pošto je u amorfiji poimanje života zapravo naslućivanje životnog besmisla, ostaje se ravnodušnim prema tome da se baš mora srati na klozetskoj šolji. U krajnjoj liniji [...] sranje na klozetskoj šolji jeste udobnije ali je nehigijenskije nego kad čučiš u kukuruzu. Kad se ovako nešto kaže, to na pripadnike kristalne civilizacije deluje kao jeres nad jeresima. Međutim, sve je ovo istina." ${ }^{20}$

Na Pavlovićeve simpatije ukazuje i njegovo viđenje civilizacijskih utjecaja u umjetnosti. Iako najprije piše da je u toj sferi jako teško odrediti gdje jedan model završava, a drugi počinje, jer se u njoj "duhovno tkivo spliće i prepliće u nerazmrsivu igru u kojoj je poreklo i osobine pojedinih niti teško prepoznati”, ${ }^{21}$ nakon toga ipak tvrdi da je - tamo gdje se kristal i amorfija u umjetnosti mogu raspoznati - superiornost ipak na strani potonjeg. Pritom izvodi dodatni trik: upozorava da amorfno u umjetnosti "više zavisi od 'amorfnog' u stvaraocu-pojedincu nego od civilizacijskog profila zajednice kojoj stvaralac pripada".2 Očekujemo li da će Pavlović iskoračiti izvan okvira zapadnog književnog kanona, mogli bismo ostati razočarani. Podjelu na kristal i amorfiju on ilustrira razlikom između Joycea ("pojam

20 Ibid., 31.

21 Ibid., 25.

22 Ibid., 27. 
modernog tvorca kristalne proze, simbol genijalnosti forme”), i D.H. Lawrencea ("genije amorfnog izraza"). ${ }^{23}$ Naravno, nimalo ne iznenađuje da Pavlović sve omiljene književne autore stavlja na stranu amorfije: pored Lawrencea, i Dostojevski i Faulkner i Bora Stanković su mu "geniji amorfno ljudskog" te za njih rezervira status istinskih tvoraca, stvaralaca, "nasuprot kristalotvorcima, to jest izvođačima". ${ }^{24} \mathrm{Na}$ istoj liniji je i Pavlovićev vic: "OGLAS // Menjam celokupnog Borhesa za jednu jedinu priču Isaka Babelja”."s

Treće, fantazijom o dvije civilizacije dominira imperativ nesvodive supstancijalne razlike između njih. Pavlović uvjetuje njihovu apsolutnu suprotstavljenost kroz polarnost, a ne mogućnost njihovog pomirenja ili uzdizanja na višu razinu u nekoj vrsti dijalektičke sinteze. Samo na jednom mjestu Ludilo u ogledalu dozvoljava mogućnost da neka vrsta doticaja ili spoja civilizacijskih modela može imati pozitivan (štoviše, izvanredno pozitivan) ishod: "iz prožimanja različitih civilizacijskih vidova, njihovog preplitanja i međusobnog bogaćenja nastaju vrhunska dostignuća ljudskog duha. I tome se mora stremiti. Jer nam je samo tako moguć opstanak na Balkanu". ${ }^{26}$

Međutim, teško se oteti dojmu da je i ta tvrdnja tek kurtoazna ograda od teze koju je Pavlović apodiktički iznio u prethodnoj rečenici: "sa sigurnošću ćemo ustvrditi da se [...] iz sukobljenih civilizacijskih gromada — zasnovanih na različitim psihičkim stožerima, pa prema tome i na različitim mentalnim konstitucijama sa suprotnom mitskom nadgradnjom - ne može očekivati ništa dobro". ${ }^{27}$ Uopće, tvrdnja o vrhunskim dometima preplitanja civilizacija ostaje štura i nepotkrijepljena primjerima, nešto poput iznimke koja potvrđuje pravilo koje cijela knjiga elaborira na takoreći svakoj stranici: miješanje civilizacija znači samo "zlo i gore".

Za ovo razmatranje najvažnija odlika Pavlovićevog svjetonazora, glavna potka njegove civilizacijske teze jeste njegov općeniti animozitet prema modernosti u najširem smislu. U tom zazoru od modernosti, Pavlović brka neizbježne unutrašnje antagonizme same modernosti sa

23 Ibid., 26.

24 Ibid., 23; kurziv i svi drugi oblici isticanja (npr. kapitule) preneseni su iz izvornika.

25 Pavlović, Flogiston, 121.

26 Pavlović i Milanović-Zeković, 127-128.

27 Ibid. 
sukobom predmodernog i modernog, amorfije i kristala. Točnije, sama njegova pretpostavka predmodernog-amorfnog, čist je fantazmatski konstrukt kojim je reagirao na mrtvouzice modernosti. U naredna tri odjeljka, ilustrirat ću taj impuls protiv modernosti kroz Pavlovićeve teze o (1) raspadu Jugoslavije, (2) spolu i rodu, s posebnim naglaskom na "ženskom principu", te (3) političkoj revoluciji.

\section{Jugoslavija kao međucivilizacijska rasjelina}

Pavlović poklanja posebnu pažnju državama i narodima za koje smatra da se nalaze u rubnim civilizacijskim zonama u kojima se načela kristala i načela amorfije prožimaju, ali i varniče: "Deo Mediterana sa Balkanom, Rusija, Španija, Južna Amerika”. ${ }^{8}$ Kao primjere nacija koje utjelovljuju nepomirljivost različitih civilizacijskih modela navodi i Mađarsku i Japan. Mađare vidi kao "narod poreklom iz izrazite amorfije, [koji je pao] pod dugu dominaciju civilizacije kristala i katoličke vere", te pretpostavlja da je visok procenat suicida u Mađarskoj mogući efekat "raskoraka između potrebe za centrifugalnošću i oslobađanjem energija koje se civilizacijskim koordinatama i religijskim obručima sputavaju i usmeravaju ka centripetalnim ciljevima". ${ }^{9}$ I kolektivno nesvjesno japanske nacije odlikuje se raskolom "između šizofrenog (amorfnog) i paranoičnog (kristalnog)”, koji kolektivno erumpira u posebno sadističkim i bestijalnim ratovima i agresijama, a individualno $\mathrm{u}$ harakiriju kao ritualnom samoubojstvu "izrazito mazohističkog karaktera". ${ }^{30}$

I političku kataklizmu Jugoslavije Pavlović objašnjava time što je zemlja bila smještena na rasjedu između dviju civilizacija: jugoslavenski su narodi bili "na graničnim rubovima oba civilizacijska bloka, [...] jednim delom svog kolektivnog bića čvrsto vezani za amorfiju a drugim [...] upoznali i kušali čari civlizacije kristala". ${ }^{31}$ Amorfija i ovdje ima status izvornog stanja, i to u okvirima širim od jugoslavenskih. Naime, prema Pavloviću, cijela "slovenska rasa" ("slovenstvo"), izvorno pripada civilizacijskom obliku koji je suštinski amorfan, "čak i u onim sredinama koje su se preko religija uključile u sfere civilizacije kristala kao što je slučaj sa Poljacima, Česima, Slovacima, Slovenci-

28 Ibid., 24.

29 Ibid., 133.

30 Ibid., 5o.

31 Ibid., 76. 
ma i Hrvatima". ${ }^{32}$ No, kod ovih je naroda spoj iskonskog-amorfnog i novousvojenog-kristalnog rezultirao konfliktom koji je imao pogubne posljedice:

"Kao što znamo, Hrvati, Slovenci, Česi, Slovaci i Poljaci podležu svojevremeno katoličkoj invaziji na štetu praiskona u sebi, i suzbijeno paganstvo u njima snažno pervertira u mržnju i zločin: mržnju Poljaka katolika prema Rusima pravoslavcima, mržnju Slovenaca i Hrvata katolika prema Srbima pravoslavcima, i zločin Poljaka prema Jevrejima, a Hrvata katolika prema Srbima, Jevrejima i Ciganima - dokaz, pored mnogih drugih, da pervertovane kristalne civilizacije, obično sa kulturnih margina kristalnih civilizacija (jer, biološki, pripadaju amorfnoj civilizacijskoj morfologiji), ne podnose biološku superiornost horizontalnih, starih ali trajnih, sa svojim religijskim uzusima usklađenih amorfnih civilizacijskih formacija." ${ }^{33}$

U kontekstu raspada Jugoslavije, Pavlovića najviše privlači srpsko-hrvatski sukob, točnije, Hrvati koji - opetuje on - pate od unutrašnjeg razdora između "nostalgije za amorfijom, koja je Hrvatima ugrađena u gene, i religijske koordinacije, usmerene ka interesima civilizacije kristala”; nasuprot svojoj “amorfnoj genetici”, Hrvati su, posredstvom katoličanstva, "uterani" i "prinuđeni da budu" u civilizaciji kristala. ${ }^{34}$ Potvrdu ove teze Pavlović nalazi u knjizi Rebecce West Crno jagnje i sivi soko, gdje se tvrdi kako je tragedija Hrvata u tome što su njihova religija i njihova "rasna pripadnost" međusobno suprostavljene. ${ }^{35} \mathrm{~Pa}$ vlović iz toga izvlači zaključak:

"Ista rasa a druga vera je već nešto drugo no ista rasa $\mathrm{i}$ ista vera. Ta vera je nosila i nosi određene civilizacijske norme na osnovu kojih se odvijaju i biološki procesi, a sa njima i određene neusklađenosti - slučaj sa Hrvatima, koji, genski predisponirani za život $\mathrm{u}$ amorfnim civilizacijskim formama, ulaze u koliziju sa verskim instrukcijama preuzetim iz civilizacijskih zakonitosti civilizacija kristala, sasvim neprimerenim mentalnim osobinama šizofrenog kolektivno nesvesnog. Otud grdne trzavice u odnosu na pripadnike iste rase (verovatno $\mathrm{i}$ istog naroda) koji žive u paganskoj slo-

32 Ibid., 45.

33 Ibid., 44.

34 Ibid., 131.

35 Ibid., 81. 
bodi amorfnog karaktera, nesputani od katoličke vere koja njihovu braću okiva civilizacijskim koordinatama kristalnog karaktera." ${ }^{36}$

Kraj citata ilustrira Pavlovićevu predstavu o Srbima kao dijelu slavenskog korpusa koji nije frustriran unutrašnjim antagonizmom: "Ako Srbi nisu agresivni, oni to nisu (ili bar nisu do sada bili) zato što između njihove paganske praosnove i pravoslavne duhovnosti nema raseline [koja] je kod Hrvata i Poljaka očigledna". ${ }^{37}$ Razlika između pravoslavlja, na jednoj strani, i ostalih tipova kršćanstva (napose katoličanstva), na drugoj, krije se u tome što je izvorno kršćanstvo bilo usmjereno protiv civilizacije kristala (Rim). Stoga, po Pavloviću, jedino pravoslavlje "ostaje dosledno temeljnim načelima hrišćanstva [...] sakralno, neagresivno i tolerantno", ${ }^{38}$ dok u katoličanstvu vidi "jeretičku (izdajničku) crkvu”: “I kao svaki prebeg, 'poturica', ili renegat, katolička crkva, inficirana svojim jeretičkim grehom, prihvata od [kristalne civilizacije] princip pravolinijskog utilitarnog dinamizma". ${ }^{39}$ Općenito, fanatizirana, militantna i željna vlasti, katolička je crkva sastavni dio nasilničke i osvajačke infrastrukture civilizacija kristala.

U ovim je tvrdnjama lako vidjeti varijantu srpskog nacionalizma, koji se kod Pavlovića pojavljuje i pored njegove opće kritike nacionalizama svih jugoslavenskih naroda, kao i kritike konkretnih zločinačkih vojnih akcija Beograda 1991. godine. Za ilustraciju, dovoljno je navesti nekoliko rečenica iz njegovog sinoptičkog pregleda eskalacije nasilja i rata 1991. godine:

"Nacionalistička trvenja ubrzo dostižu vrhunac, socijalistički feudalci, u želji da sačuvaju regionalnu vlast, otvoreno potpiruju mržnju prema pripadnicima drugih naroda i drugih religija [...]. Šovinizam poput ubitačnog narkotika opija kolektivnu svest i snovi se više ne razlikuju od košmara: Slovenija se otcepljuje od Jugoslavije, počinje rat [...]. Ubrzo, ratni požar zahvata i Hrvatsku: vekovima željna samostalnosti, sledi Sloveniju — lokalne čarke između hrvatske policije i srpskog življa pretvaraju se u oganj; u njega se uključuje Jugoslovenska narodna armija, usput se raspadajući; bezumlje i smrt postaju sinonim za svakidašnjicu: Srbija tobože nije u ratu,

36 Ibid., 85.

37 Ibid., 44-45.

38 Ibid., 44 .

39 Ibid., 43. 
ali mobiliše seljake koji, sa dobrovoljačkim jedinicama što se malo ili ni po čemu ne razlikuju od pljačkaških bandi, seju leševima njive po Slavoniji i Zapadnom Sremu [...]." 40

Ništa u ovim rečenicama ne ukazuje da su politički ciljevi Slovenije ili Hrvatske vođeni supstancijalno drugačijim motivima od motiva Srbije. Štoviše, ako Pavlović nekoga optužuje za prijetvornost i, efektivno, zločin, to je upravo Srbija. Uostalom, samo koju godinu prije - u Flogistonu, 1989. godine - Pavlović eksplicitno proglašava takve usporedbe uzaludnim:

"BAVITI SE NACIJAMA (svojom nacijom), posao je bez svrhe: bavljenje nacionalnim osobinama podrazumeva poređenja.

Ali kako porediti svojstva brezovog drveta sa hrastovim, ili javorovim, grabovim, lipovim?

Nijedno nema nad drugim prednosti." ${ }^{41}$

Pa ipak, naknadna Pavlovićeva kritika rascijepljenosti 'Hrvata katolika' ne zrcali samo njegov animozitet prema toj etno-konfesionalnoj skupini, nego i njegov opći animozitet prema stanju "raseline", "sudara" ili antagonizma između dvaju civilizacijskih modela u kome se može naći neki subjekt. Da taj subjekt ne mora biti nužno nacionalno ili etnički označen, pokazuje i jeremijada koju Pavlović na stranicama Flogistona adresira na seljake:

"Oči tih seljaka, koji, izmešteni iz brazda, kruže po građanskim izletištima i pokraj isturenih gradskih naselja radeći na građevinama sve vrste zanatskih poslova, te oči u čijim se zenicama meša snena žeđ i oprez životinje, više ne gledaju unazad, u kolotečine vekova prepunih glibavih tragova muka i nužde predaka, već zure preda se, u mutnu daljinu, u prazno što ih, poput leptirove blještava svetlost (sic!), vuče u slepilo zadovoljstava bez obrednih međa, u bolesti tela i duše, u pustoš srca lišenog patrijarhalnog usmerenja, u jezovitost osamljeničke smrti. Hoće da imaju, pa otimaju, grabe, gubeći, u pomami, tačnu predstavu šta je čije, šta je njihovo a šta tuđe, deleći, u sebi, još uvek svet na 'moje' i na 'ničije' po uzoru na seljake pradedove, ali već se stideći onog što su nasledili, pa hitaju da i to što imaju preobrate u ono što bi želeli da imaju, proizvodeći tako, na razmeđi civilizacija, nakazne oblike života koji više ne

40 Pavlović, Planeta filma, 240.

41 Pavlović, Flogiston, 124. 
pripadaju ni drevnoj seoskoj civilizaciji nužnosti, niti tek onjušenoj urbanoj civilizaciji zadovoljstva: njihova prebivališta sve više podsećaju na neuspelu imitaciju modernih palanki, a palanke i gradovi u koje nadiru nezadrživo, poput termita, svojim nasleđenim navikama razaraju i dekomponuju u poseljačena boravišta, prema kojima, iskorenjeni iz običaja i tradicija, imaju, negde duboko u srcu, odnos kao prema robijašnicama među čije su se zidine (sic!) obreli ne svojom voljom već pod tuđom prinudom." ${ }^{42}$

Pavlovićeva slika seljaka tako nudi jednu od brojnih inačica na temu plemenitog divljaka koji svoju izvornu plemenitost (tradicionalnu mudrost, neposrednu uronjenost u prirodu, i sl.) može sačuvati jedino ako ne popusti izazovima civilizicije kristala; u suprotnom, oni greznu u korupciji i pretvaraju se u nakaznu hordu koja nezadrživo "poseljačuje" civilizaciju kristala. Kao i u drugim sličnim slučajevima u kojima imamo ovu dinamiku (npr. u reprezentacijama "orijentalnog" i "egzotičnog” drugog), ispod sentimentalnog odnosa prema pretpostavljenom skladu organskog-predmodernog (pavlovićevski rečeno: amorfije), vrebaju najrazmetljivija (kultur)rasistička netrpeljivost $\mathrm{i}$ mržnja. Od Pavlovićeve bujice pogrda na račun nakaznih i grabežljivih seljaka, više govori jedino njezin povod:

"Kada sam im jednog dana dao da pročitaju pesmicu iz Crvenog bana, gledali su me belo. Očekivao sam razuzdan smeh, a sučelio se sa nerazumevanjem, ili s dobro prikrivenim stidom". ${ }^{43}$

Jedino istinsko nerazumijevanje u ovom susretu urbanog intelektualca iz srednje klase sa seljacima jest Pavlovićevo nerazumijevanje vlastite pozicije iz koje mu se Crven ban - kolekcija narodne poezije s erotskim motivima, koju je sakupio i priredio Vuk Stefanović Karadžić — čini kao organski plod autentične tradicije u koju bi i seljaci u drugoj polovici 20. stoljeća trebali biti uronjeni kao i njihovi preci. Iznevjerivši njegova očekivanja i uskrativši mu smijeh — vrhunski potvrdu toga da ih on zapravo poznaje bolje od njih samih — seljaci su naprosto razotkrili Pavlovićevu nemoć da ih prepozna i uvaži kao autentične subjekte modernosti. Cijena toga su spektakularne optužbe na njihov račun: njihova reakcija je za njega dokaz da se nekadašnja kreativnost seljaka pod utjecajem kristalne civilizacije

42 Ibid., 105.

43 Ibid. 
“izvitoperava [...] u strahovitu destrukciju, a duh dionizijske seksualnosti, prisutan u starim erotskim pesmicama [...] degeneriše se u samosažalni plač nad emotivnom zbrkom, proisteklom iz pohlepe, koja ih, u zasopljenom jurišu na hipnotička zadovoljstva civilizacije grada, otrže od temelja, korena i smisla." ${ }^{4}$

I zbilja, imajući u vidu sve ove atribute kojima je Pavlović počastio seljake - neusumnjivo, srpske seljake — zbog navodne rascijepljenosti između dviju civilizacija, čini se da su 'Hrvati katolici' još i dobro prošli.

\section{Civilizacijski sudar spolova}

Ako sam Pavlovićev animozitet prema modernosti do sada ilustrirao njegovim tezama o raspadu Jugoslavije, mogli bismo zaključiti da je njegov polarni civilizacijski model naprosto posljedica tog historijskog konteksta: suočen sa postjugoslavenskim “smakom sveta”, Pavlović je stvorio formulu najzaoštrenije civilizacijske dihotomije i radikalno je generalizirao na modernost kao takvu. To je jednim dijelom istina: vjerujem da možemo reći da je traumatična razgradnja Jugoslavije doprinijela tome da finalna verzija teze o civilizacijama, izložena na stranicama Ludila u ogledalu, izgleda krajnje dramatična i katastrofična. Ali, čak i prije nego što je našao tako dramatičnu "potvrdu", Pavlovićev je svjetonazor u svojoj osnovnoj strukturi - formuli polarne dihotomije - uvijek bio imanentno antimoderan.

Najbolja ilustracija toga je način kako je Pavlović svoj civilizacijski model primijenio na problematiku spola i roda: cijeli niz ocjena $i$ tvrdnji o ženi i muškarcu (ženskosti i muškosti), seksualnosti, braku, porodici i sl. Iako pitanja spola i roda mogu izgledati ekscentrična u odnosu na uvodni primjer raspada Jugoslavije, zastupam tezu da su upravo ta pitanja temelj cijelog Pavlovićevog pothvata: njegova razmatranja o, recimo, ženi i "ženstvu” kao načelu amorfne civilizacije sasvim sigurno prethode njegovim fantazijama o Hrvatima. Pri tom ne smijemo zaboraviti na udio erotike u Pavlovićevom stvaralaštvu općenito. Scene seksa bile su jedan od njegovih zaštitnih znakova i u filmu i u književnosti, nesumnjivo doprinijevši njegovom statusu 'autora'. Indikativno je, iz filmološke perspektive, da Pavlović nije napisao nijedan esej kojim bi detaljnije elaborirao spolnost, seks i njihovo predstavljanje na filmu te se čini da se njegov tretman erotike općenito uklapa u njegove estetske koordinate "surovog" i "odvratnog". Nekoli-

44 Ibid. 
ko intervjua barem donekle prenosi određene specifičnosti njegovog pogleda na odnos seksa i roda s filmskom umjetnošću. U najkraćem, Pavlović priznaje da se prema seksu odnosi "kao prema nekoj mutnoj jami koja guta i proždire", odnosno da u njemu vidi "oblast u kojoj se [čovek] najviše udaljava od sebe kao svesnog bića, u kojoj učestvuje u primicanju nečemu što je domen strave i iščeznuća". ${ }^{45} \mathrm{Na}$ tu užasavajuću dimenziju seksa, Pavlović na filmu reagira tako što izbjegava estetizaciju: "u tim situacijama nema estetike, to je goli život, praštanje čulnosti, doticanje sa smrću”. ${ }^{46} \mathrm{U}$ tom pogledu, Pavlović fetišizira seks, pridajući seksualnom iskustvo radikalno drugačiji status nego ostalim aspektima ljudskog postojanja. ${ }^{47}$

Vratimo li se civilizacijskom modelu, za Pavlovića su "CIVILIZACIJE NUŽNOSTI = ženske civilizacije (civilizacije uzgajanja života / ne 'napretka', 'progresa', 'rasta'!). Civilizacije patnje i bola. Civilizacije koje ne traže svoj (tj. životni) smisao"; nasuprot tome, "CIVILIZACIJE ZADOVOLJSTVA = muške civilizacije. $(\mathrm{Tj}$. civilizacije orgazma. Tj. umetnosti. Tj. smrti.)”. ${ }^{8} \mathrm{U}$ nastavku ću kompilirati samo nekoliko njegovih naglasaka koji, nadam se, daju glavni nacrt rodne dimenzije Pavlovićeve dihotomije i njezin inherentni seksizam:

"Muškarac: izbacivanjem semena naslućuje smrt.

Žena: primanjem semena (za oplodnju) naslućuje život." ${ }^{49}$

"Kod muškarca, orgazam je prevashodno fizički faktor. U složenoj gradskoj civilizaciji, u kojoj je nagon iz funkcije izopačen u zadovoljstvo, orgazam je i psihofizička činjenica.

Kod žena (Žena gradske civilizacije), orgazam je samo psihički faktor." ${ }^{0}$

45 Pajkić, Jahač na lokomotivi, 107.

46 Ibid., 106.

47 Potrebno je istaknuti da je Pavlović veoma različito tretirao erotiku na filmu i književnosti. "Erotske scene gotovo u svim njegovim filmovima izvedene su majstorski, s ukusom i mjerom, poetične su, duhovite, dok je sve to u romanima na rubu banalnosti i pornografije, čak nevješto i jezično odurno, kao da je sve smišljeno da izazove gađenje na seks" (Kovač, "Kao svinje u blatu”, 476). Razlika između ovih dvaju registara reprezentacije erotike kod Pavlovića — još jedan od njegovih antagonizama! - tek očekuje ozbiljnu analizu.

48 Pavlović, Flogiston, 24-25.

49 Ibid., 14.

50 Ibid., 21. 
"SAMOUBISTVO = hermafroditski čin. Pokušaj da se bude između (duha civilizacije nužnosti, tj. civilizacije 'ženstva', i duha civilizacije zadovoljstva, tj. civilizacije 'muštva'). Poslednji stepen izopačenja svesti (bolje reći: individualnog duha)."

“DOKJEBEŠ, dok si u ženi, dok istureni deo svoga tela (svoje utrobe) tareš o vlažne zidove određenih udubina u ženskom telu, ti zamišljaš da si u ženi koja, trljana tvojom cevastom izbočinom, iskače iz mirnih i uhodanih životnih užlebljenja, i predaje se strahotnim telesnim kontrakcijama, od čega, dok žmuriš, i tareš se, i zamišljaš kako se tareš, i tebe ophrvava neopisiva bolnousmrćujuća slast ne bi li te spopali samrtni grčevi kako bi, obeznanjen, iz svoje utrobe izbacio u tu ženu, u kojoj jesi, ali istovremeno i zamišljaš da si u njoj, oplodno seme, i, potom, zamro, zgrožen nad sobom i njom, a pre svega, nad slikama tog istog prizora, i tebe i nje, koju, posle pražnjenja, mrziš kao svog životnog neprijatelja — eto jedne od najvećih, nerešenih, i nerešivih tajni." ${ }^{2}$

“ŽENA JE ILI MAJKA ILI KURVA. U prvom slučaju čezne da se njome vlada; u drugom da vlada ona.

U životu se obično smenjuju periodi u kojima je žena čas jedno a čas drugo. Ali nije redak slučaj da se u istom biću dve osobenosti istodobno prepletu. I tad u takvoj ženi zavlada zbrka. A muškarci, iznenađeni i zbunjeni difuznim ponašanjem, obeležiće je kao osobu punu tajni. I, u želju da je osvoje, izložiće se velikoj pogibelji. Jer u njoj, ispod prividne stišanosti, ključa smrtonosni vir. I taj kovitlac ne samo nju, već i onog ko je sa njom, odvlači na dno.

Za takve prirode izmišljeno je poetsko obeležje: les fammes fatalles (sic!).",33

“ZA RAZLIKU OD ČOVEKA KOJI MISLI, žena je odsustvom mišljenja samo na dobitku. Njen osnovni biološki smisao ne dozvoljava joj da se postavi nasuprot svetu; reklo bi se: organski ne podnosi nesklad između sebe i života. Zato će iskoristiti prvu priliku da se prepusti bilo kakvoj vrsti senzacija.

Da zadovolji glad čula.

Da se otarasi bremena razmišljanja.

51 Ibid., 25.

52 Ibid., 104.

53 Ibid., 112. 
Prepuštajući se nerazumlju, služi životu. ${ }^{\$ 4}$

"ISUVIŠE LEP STIL sličan je isuviše lepoj ženi: oboje su egocentrični i samodopadljivi, oboje uživaju u sopstvenoj lepoti i radije su okrenuti ogledalu nego životu. Jer isuviše lep stil, kao i prelepa žena, nije na početku životnih procesa no na njegovom kraju: oni ne pripadaju trenutku plođenja, no gnjilenja.

Zato je isuviše lep stil, kao i lepotica, često besplodan." 55

"Inteligencija u duhovnom korpusu žene ne razlikuje se od slepog creva - od nje nikakve koristi." ${ }^{6}$

U pogledu 'ženskog pitanja’ Nietzscheov utjecaj na Pavlovića bio je posebno poguban. U Flogistonu kao da nema nijednog mizoginog Nietzscheovog aforizma kojem je Pavlović odolio: "Ti ideš kod žena? — Ne zaboravi bič"; "U životu žene sve je zagonetka, i sve u ženi ima jedno rešenje koje se zove porođaj”, i sl..$^{57}$ Ipak, ovdje nije riječ naprosto o tome da Pavlović reciklira pojedine Nietzscheove teze, nego još i više ono što prepoznaje kao njegov stav. Nažalost, rekao bih da upravo zbog te poze njegova razmatranja izgledaju ujedno apsurdno ambiciozna, beznadežno anakrona i nenamjerno komična - nešto poput Otta Weiningera koji je na kraju 20. stoljeća odmrznut iz kriogene komore. Asocijaciju dugujem Srbi Ignjatoviću koji u pogovoru za Flogiston primjećuje: "neobično je to što će mnogo koja Pavlovićeva teza zazvučati saglasno Vajningerovima tumačenjima iz Pola $i$ karaktera". ${ }^{8}$

No, zadržimo se nakratko pri jednom drugom autoru koga Ignjatović ističe, pored Nietzschea, kao Pavlovićevu "duhovnu okosnicu” - Freudu. Naime, nema sumnje da je Pavlović čitao Freuda i da je želio ponoviti nešto i od njegove geste. Opozicija između nužnosti i užitka neusmnjivo zrcali Freudovu opoziciju načela ugode i načela stvarnosti; Pavlović citira i Freudovo pitanje "Što žena želi?" No, teško da se može govoriti o istinskoj aproprijaciji psihoanalize. Štoviše, cijela Pavlovićeva pretpostavka o polovima kolektivnog nesvjesnog zapravo je antifrojdovska. Čini se da je Nietzsche, u tom

54 Ibid., 113.

55 Ibid., 147.

56 Ibid.

57 Ibid., 98.

58 Srba Ignjatović, “Čari atipične proze: Flogiston i Belina sutra Živojina Pavlovića”, u: Pavlović, Flogiston, 1989, 171. 
pogledu, daleko zahvalniji za usvajanje: njegovi su aforizmi naizgled daleko jednostavniji i jasniji od složenih psihoanalitičkih konstrukcija. Naravno, to je privid, te stoga Pavlovićevo "razumijevanje" i citiranje Nietzschea u konačnoj analizi izgleda opscenije i promašenije od aluzija na Freuda.

Navedimo ovdje, za ilustraciju teškoće, i tekst Branislava Dimitrijevića "Sufražetkinje, radodajke i lažne trudnice", psihoanalitičko čitanje filma Kad budem mrtav i beo. Iako Dimitrijević izbjegava oštru kritičku konfrontaciju s Pavlovićem, svejedno eksplicitno ukazuje na seksizam u njegovoj reprezentaciji žena. Sama završnica teksta radikalno je višeznačna:

"Što se reprezentacije ženskosti tiče, odnos Živojina Pavlovića na kraju ipak ne ispada ništa više ciničan od onog Frojdovog zaključka u eseju o 'Ženskosti’. A Frojd kaže: 'Ovo je sve što sam imao da vam kažem o ženskosti. Sve je ovo svakako nekompletno i fragmentarno i ne zvuči uvek prijateljski naklonjeno... Ako želite da znate više o ženskosti, razmotrite vaša sopstvena životna iskustva, ili se obratite pesnicima, ili sačekajte dok nauka ne bude u mogućnosti da vam da dublje i koherentnije informacije." 59

Iako se čini da Dimitrijević kroz direktnu usporedbu s Freudom brani Pavlovića, u njoj je moguće prepoznati i ironiju: Pavlović je iznevjerio Freudovo povjerenje ('obratite se pjesnicima') upravo kao umjetnik - njegov rad pokazuje da, i nakon toliko vremena, umjetnost i dalje proizvodi seksističke predstave žena.

No, Pavlovićevi stavovi o "ženstvu” posebno su značajni za razmatranje njegovog civilizacijskog modela jer nisu samo jedno od polja na koja on primjenjuje načelo civilizacijske podjele. Oni su upravo ono polje kroz koje je partikularnu problematiku spola/roda univerzalizirao u model civilizacijskog sukoba. Spolnu je razliku pojmio kao poslovični, zdravorazumski rat spolova, dao joj status dihotomije i uzdigao na nivo sukoba civilizacija. Seksizam je neizbježni efekt te operacije. U tom pogledu ilustrativne su njegove izjave već s kraja 1960-ih, poput onih u intervjuu za Polet 1968. godine:

"Meni su i neke druge stvari veoma zanimljive, ali nemam snage da uđem u njih; recimo - žena, žena u našem vremenu. Potpuno

59 Branislav Dimitrijević, "Sufražetkinje, radodajke i lažne trudnice: Žene u filmu Kad budem mrtav i beo", u: "Kad budem mrtav i beo"-film Živojina Pavlovića, ur. Branislav Dimitrijević et al. (1997), 17. 
nedotaknuto, strašno zanimljivo pitanje. Žene su po svojoj prirodi daleko vitalnije, elastičnije, emotivnije i manje racionalne od muškaraca, pa i mnogo teže za definisanje. U tome se kriju izvesne draži, jer žene su večne, stalno iste u svojim vibracijama. Ljudi 19. veka su, recimo, u mnogo čemu drugačiji od naših očeva, i to na mnogim planovima. Kod žena, međutim, svest nije toliko primarna; i tu se kriju te velike draži. Ali, ja nemam moći da to sada oblikujem." ${ }^{\prime 0}$

U svjetlu ove tvrdnje, sva ona pozivanja na Nietzschea u Flogistonu dolaze prekasno i odveć su redundantna. Već ovdje imamo posla s Pavlovićevom ženom, napravljenom po ničeanskoj recepturi vječite, nepromjenjive ženskosti. U jednom od svojih protuslovlja, Pavlović prvo tvrdi da ga zanima “žena u našem vremenu”, da bi je već u sljedećem dahu pretvorio u ahistorijsku utvaru: ona mu je zapravo ista kao i žena u 19. stoljeću, njezina se racionalna svijest nije razvijala kao kod "ljudi”, što je pojam koji Pavlović ovdje rezervira za muškarce. Drugi odgovor $u$ istom intervjuu otkriva $u$ čemu vidi inertnu supstanciju žene. Govoreći o razvoju suvremene civilizacije, on primjećuje tendenciju da se tehnološkim razvojem ukloni ili smanji ljudska patnja:

" $U$ to sve ulazi i napor da se ukloni bol, ali takvi napori ili degenerišu sam život ili doživljavaju poraz. Na primer, napor da se eliminiše bol dovodi do otromljavanja materinske sile. Medicina je došla do tako izvrsnih rezultata da žena može da se porađa bez ikakvog osećanja bola. Međutim, eliminacijom bola, eliminiše se i nešto $u$ samoj strukturi žene, jer $u$ isto vreme dolazi do pojave indiferentnosti prema ostavljanju potomstva — sve se odražava na vitalitet ljudske rase." ${ }^{11}$

Kao u razradi Nietzscheovog aforizma da "sve u ženi ima jedno rešenje koje se zove porođaj”, Pavlović i taj porođaj svodi na iskustvo boli-boli koja po njemu ostaje ahistorijska kategorija one patnje koja određuje ženu i njezinu glavnu biološku i društvenu funkciju. Žena koja ne pati pri porodu postaje ravnodušna prema potomstvu, njezina 'materinska sila' postaje 'troma', i sve to ugrožava vitalitet ljudske rase. ${ }^{62} \mathrm{O}$ 'očinskoj sili', njezinoj prirodi i efektima, Pavlović

60 Pavlović, Đavolji film, 235-236.

61 Ibid., 229.

62 Na sličan način, Pavlović spominje "pogubnu ulogu majke u životu i razvoju, a i osipanju savremene srpske porodice” (Flogiston, 135), ali je ne objašnjava. 
postojano šuti; uostalom, nigdje i ne pokušava svesti muškarce na očinsku funkciju.

Definirane na ovaj način, žene za Pavlovića ne mogu biti istinski agent modernosti. Sama supstancija žene — bol kao temelj materinske sile - stoji u potpunoj opreci prema modernosti: dok modernost donosi novìne na svakom planu ljudskog postojanja, bol kao srž ženskog načela mora ostati nepromijenjena, a materinska sila ostati vitalna u nekom pretpostavljenom iskonskom modalitetu. Upravo ta bol i patnja majke nude savršenu sinegdohu nužnosti koja određuje amorfnu civilizaciju kao žensku civilizaciju. Odnosno, 'amorfna civilizacija' i nije drugo nego partikularno iskustvo porođajne boli i trpljenja podignuto na eksponenciju univerzalne vrijednosti.

Otud Pavlović ne štedi na pogrdama kada je riječ o borbi za rodnu ravnopravnost, odnosno bilo koji pokušaj žena da ublaže bol i patnju, da ukažu da patnja nije nužnost i njihova sudbina, ili da - scenarij koji Pavlovića najviše užasava - posegnu za ugodom i zadovoljstvom. Tako u Flogistonu čitamo:

"SEKSUALNA REVOLUCIJA nije ništa drugo do pobuna žena: glad za zadovoljstvom sa stanovišta mašte. Kako orgazam u žene ne zavisi od telesnog dodira, već od fantazione narkotizovanosti (tj. od boljeg ili lošijeg funkcionisanja složene duhovne aparature čije aktiviranje uslovljeno samo telesnom delatnošću), i 'seksualna revolucija', kao i svaka iluzija, doživljava poraz.” ${ }^{63}$

\section{"SLOBODNA ŽENA}

Osamostaljujući se, savremena feministkinja sebe lišava poroda, a seks (zadovoljstvo) diže na pijedestal Boga. Bežeći od rađanja (patnje) i služeći civilizacijskoj koncepciji slobode, ona u stvari postaje emotivni invalid i rob organizacije - te i motorne i kohezione sile subcivilizacije kojoj pripada. Ne vidi da je moderna civilizacija, goneći na fetišiziranje Uma i Zadovoljstva, u stvari najveći njen tlačitelj.

Mekša varijanta feminizma: individualnost i Sloboda Žene, ali sa rađanjem, i u okviru Porodice - u stvari ne rešava problem koji će se, možda, rešiti s propašću Zapadne civilizacije, ukoliko normativi Napretka, Progresa, tj. Takmičenja, ne budu pokopani zauvek. I ako pouke Prirode ne nagnaju ljudski rod da iz sebe izluči nove normative koje savremeni Um neće moći shvatiti. To

63 Ibid., 8. 
jest, tek ako moć muškog roda sasvim sjenja i čovečanstvo potone u bezgranično gluvo blaženstvo Matrijarhata, i tako se primakne biti Kosmosa." ${ }^{64}$

Pavlovićev tretman ove teme u Ludilu u ogledalu posebno je zanimljiv s obzirom na to da je tom prilikom sve ove fragmente o spolu i rodu, i posebno ženama, pokušao sistematično izložiti upravo u razgovoru s jednom ženom, nudeći vrhunski primjer onoga što danas zovemo mansplaining. Ovdje treba istaknuti da, iako novinarku Dušanku Milanović-Zeković teško možemo nazvati istinski ravnopravnom sugovornicom, jer u najvećem dijelu knjige čak ni ne postavlja pitanja Pavloviću nego servira šlagvorte za njegove duge elaboracije, tim je upadljivije njezino neslaganje s Pavlovićevim tezama o ženama-jedino istinsko varničenje u knjizi:

"[MILANOVIĆ-ZEKOVIĆ:] Amorfne civilizacije — civilizacije ženskih principa. Zašto je onda položaj žena u tim civilizacijama mnogo lošiji nego tamo gde civilizacije opstaju na muškim principima?

[PAVLOVIĆ:] Ko ti to kaže? To je tako samo po merilima civilocentričnih shvatanja.

[MILANOVIĆ-ZEKOVIĆ:] Ipak, i dalje smatram da je žena na Zapadu, u demokratskim društvima, ili kako ih vi nazivate — kristalnim civilizacijama, slobodnija u odlučivanju o samoj sebi nego što je to slučaj o zemljama amorfije.

[PAVLOVIĆ:] Jeste, ona je oslobođena, ali u jednom perverznom smislu, upravo u onom smislu u kome Hrvati misle da su u boljoj situaciji zato što su katolici, a u stvari su rascepljeni između svog osnovnog genetskog pripadništva Slovenstvu i pritiska što ga trpe od katoličanstva koje ih silom sateruje u civilizacijske koordinate koje im nisu prijatne, jer su kockaste, mondrijanovske. Isto je slučaj i sa ženama. U kristalnim civilizacijama tzv. 'emancipovana' žena je, kao i moderni, tj. pomalograđanjeni proletarijat — korumpirani rob. [...]

[MILANOVIĆ-ZEKOVIĆ:] Imate sreću što ne razgovarate sa vatrenom feministkinjom... [...] Hrabrost je na kraju XX veka tvrditi da je žena srećnija, recimo, kod Homeinija nego u Švedskoj. Riskantno, rekla bih.

64 Ibid., 27. 
[PAVLOVIĆ:] Nije nimalo slučajno da u Švedskoj svaka druga žena ima dete s nekim crncem..." ${ }^{65}$

Štoviše, Pavlović na ovom mjestu u cjelosti prenosi pjesmu Slavka Mihalića "Napuštena žena" u kojoj lirski subjekt govori o "moru napuštenih žena', koje se - razočarane ljubavnicima koji su ih napustili-odlučuju na samostalan život, odnosno život bez muškaraca kao bračnih partnera:

"Preplavljuju gostionice i druga mjesta koja im nepravom bijahu oduzeta, puše, naručuju skupa pića, jedu što im nimalo ne žudi nepce, i tako im se rijetko s usana otrgne pjesma.

Stabla su koja je spalio grom i sad iz njih klija podivljalo rastinje i kad bi htjele više ne bi mogle obustaviti svoju izmijenjenu sudbinu.
$[\ldots]$
Čemu onda kupuju najljepše haljine?
Možda da pred novim svijetom, kojemu su potajne vladarice, sakriju prazninu što im niče umjesto tijela, ili se to spremaju na neki posljednji, sveuništavajući ples." ${ }^{66}$

Pjesma je Pavloviću dokaz, i to vrlo drag dokaz, da "tragediju 'civilizovanih žena” ne uočava samo on - u cjelosti ju je naveo već u Flogisto$n u .{ }^{67}$ Čini se da Pavlović, poput Mihalićevog lirskog subjekta, u životu savremenih "napuštenih žena" vidi samo neautentične geste koje ne mogu dati smisao njihovim životima. Što one više nastoje živjeti po svojim vlastitim pravilima, to su njihovi pokušaji jadnije i uzaludnije imitacije života. Čak i dok priznaje da su bile nepravedno zakinute, pjesma u tome ne vidi dovoljan, opravdan razlog za njihovu reakciju koju opisuje kao nekontroliranu i iracionalnu ("podivljalo rastinje", "bijesno sjedaju u automobile”). Čini se da je jedini autentični poten-

65 Pavlović, Ludilo u ogledalu, 55-58.

66 Ibid., 58-59.

67 Ibid., 58. 
cijal koji lirski subjekt vidi u tim "nesretnicama” još jedino mogućnost da sasvim unište svijet ("posljednji sveuništavajući ples”). Čak i kad žene lišava svakog smisla i pripisuje im želju za seksom — točnije, pogotovo tada - mizogini pogled prepoznaje u njima razarajući kapacitet. Ako je Mihalićeva pjesma suvremena razvučena parafraza onog "hell hath no fury like a woman scorned", Pavlović bi to prezrena upotpunio ili zamijenio sa slobodna, ili naprosto moderna.

\section{Revolucionarni kontrarevolucionar i kritička ljevica}

Pavlovićeva civilizacijska razlika - mislim da to sad više nikoga ne može iznenaditi - diktira i politički ustroj pojedinih država. Demokracija je kao "ideal paranoične političke svesti", ${ }^{68}$ inherentna kristalnoj civilizaciji i nekompatibilna s amorfijom: "Demokratija u amorfnim civilizacijama nema šta da traži, jer u njihovim zajednicama takva duhovna potreba na postoji”. ${ }^{69} \mathrm{Na}$ drugoj strani, kristalna civilizacija nekompatibilna je s komunizmom: "Ni u jednoj državi [...] civilizacije kristala komunistička revolucija nije uspela. Niti u jednoj. [...] Uspele su samo u sredinama u kojima su vladali drugi civilizacijski okviri (Rusija, Jugoslavija, Kina, Kuba, Vijetnam)" ${ }^{70}$ Štoviše, Pavlović $\mathrm{u}$ komunističkoj revoluciji vidi pobunu protiv kristalne civilizacije kao takve. Zato je i stavlja u istu ravan s ostalim političkim pokretima kojima pripisuje namjeru da sačuvaju amorfiju od modernosti. Otud za njega nema suštinske razlike između sovjetske revolucije i islamske revolucije u Iranu — prva je htjela zaustaviti uspostavu kristalne civilizacije (kapitalističkog sistema) u Rusiji, a druga se suprotstavila analognom pokušaju Reze Pahlavija da 'kristalizira' Iran.

Pavlović nedvosmisleno tvrdi kako se "komunistička revolucija u praksi svodi na običan gangsterski čin” jer se ne može osloboditi mehanizma terora. ${ }^{71}$ Prvo, tu je teror turbulencije revolucije, koji je usmjeren centrifugalno, prema vani, protiv kapitalizma; kasnije, Partija i Vođa koriste teror da bi tu centrifugalnu energiju nasilno preusmjerili "ka određenom cilju — stvaranju novog društvenog sistema, nove organizacije i nove hijerarhije vrednosti”."2 Komunistički se Vođa u

68 Ibid., 68.

69 Ibid., 69.

70 Ibid., 72.

71 Ibid., 74 .

72 Ibid., 73 . 
tom potezu, paradoksalno, razotkriva na strani logike kristala jer želi stvoriti nov sistem; otud je, po definiciji, paranoičan. Nasuprot njemu, revolucionarna masa ostaje "uvek pod bičem šizofrene centrifugalne energije". ${ }^{73}$ Tipski primjer ovog terora paranoičnog/kristalnog načela nad šizofrenim/amorfnim masama, za Pavlovića je "KOLEKTIVIZACIJA SELA: nasilje pervertiranih ideologija gradske civilizacije nad spontanim egzistiranjem civilizacija zemljodelaca". ${ }^{74}$

No, Pavlović ne ostaje samo na tvrdnji da je komunistička revolucija strukturno nemoguća u kristalnoj civilizaciji. U finalnom udarcu koji zadaje marksističkom nasljeđu, Pavlović tvrdi da proletarijat - kao "šljam kristalnih civilizacija",75 "talog i šut civilizacije kristala" — "nije zainteresovan da izvodi šizofrene revolucije, nego da [...] sam sebe obnavlja kroz energiju koju iz njega oslobađa revolucija u civilizaciji kristala - kroz fašističku revoluciju"."7

I ovaj Pavlovićev radikalni obračun s nekim od glavnih postulata marksizma također ima svoju višegodišnju genealogiju. Vratimo li se opet na kraj 1960-ih, vidjet ćemo da već u njima, govoreći o studentskim prosvjedima 1968. godine (implicitno: o njihovoj revolucionarnosti), Pavlović zapravo depolitizira revolucionarna politička gibanja. Sami studentski protesti po njemu su izraz vremena u kome ideološko više ne igra nikakvu važnu pokretačku ulogu: “živimo u vremenu u kojem je došlo do presušivanja ideja i ideala u ime kojih je [...] dolazilo do društvenih potresa, revolucija, lomova, menjanja klasa, kasti, vlasti". ${ }^{78}$ Iako studenti prosvjeduju, oni to čine protiv određenih praksi, ali ih pritom ne vodi nikakva jasna ideja o političkim alternativama - štoviše, ostaju zaglavljeni u marksističkoj ideologiji: "Mislim da ovi potresi neće imati neku veću perspektivu, iz njih se neće odmah izlučiti neke nove ideologije. [...] Ovi se trzaji ne čine u ime neke nove ideologije, već u ime te [marksističke] ideologije koju demantuje život", tvrdi u intervjuu za Polet 1968. godine. ${ }^{79} \mathrm{~Pa}$ ipak, ne smatra da su gibanja suvišna i beznačajna: "ti trzaji, ma kakvi da su, vrlo su dragoceni, jer

73 Ibid.

74 Pavlović, Flogiston, 14.

75 Pavlović, Ludilo u ogledalu, 72.

76 Ibid., 75.

77 Ibid.

78 Pavlović, Đavolji film, 259.

79 Ibid., 228. 
regeneriraju situaciju u društvu, unose nemir koji otvara fistule iz kojih curi gnoj, dok se sa druge strane društvo transfuzionira i osvežava. To je i cilj svake revolucije sa vitalne, biološke tačke gledišta”, ${ }^{80}$ izjavljuje za Polet, te svoju poantu ponavlja naredne godine u intervjuu za Susret: "Revolucije [...] jesu plod bioloških nužnosti, a ideje koje su se pojavljivale uz njih jesu neophodni narkotički prepadi na ljudsku svest da bi ona bila sposobna da stvar dovede do kraja". ${ }^{81}$

Jedva dvadeset godina kasnije, na stranicama Flogistona, Pavlović će ponuditi novu varijaciju na istu poantu:

"REVOLUCIJE [...] nisu ništa drugo do pobuna manje inteligentne no biološki snažnije većine protivu inteligentnije, ali biološki inferiornije manjine, s namerom da se dokopa njenog obilatog vlasništva. U stvari, kao da se radi o obračunu dva životna koncepta: pripadnici civilizacije nužnosti svete se nosiocima civilizacije obilja i zadovoljstva. Jezgrovitije kazano: reč je o nasrtaju pervertirane inercije na usahlu kreaciju. Pravda, sloboda, jednakost — samo su omama trezvene pameti: $u$ divljanju iracionalnih sila razum nema šta da traži." ${ }^{2}$

Skoro da možemo postaviti pravilo zakonitosti: kad god Pavlović spomene biologiju i vitalnost, imamo problem. Sjetimo se da se i njegova mistifikacija seksa svodila na argument kako se seks kod čovjeka ne može svesti na biologiju, a i marksistički-komunistički poziv za ravnopravnošću i jednakošću zapravo se protivi prirodnom stanju: "životna silina neće da zna za jednakost, ravnopravnost, zdravlje svih kao ni za istu pamet i jednake sposobnosti, i melje i uništava takve i slične namere". ${ }^{33}$ Jedina jednakost koju revolucija donosi po Pavloviću jeste jednakost patnje. Naime, prema jednoj od njegovih najciničnijih tvrdnji, dok su prije revolucije patili samo potlačeni, nakon nje pate - svi:

"[Većina] posle 'revolucionarnih promena' dospeva u goru situaciju od one u kojoj se, za vladine kreativne elite, nalazila: blago elitne manjine grabi za sebe revolucionarna elita, a mnoštvu ostaju beda, fraze o srećnijoj budućnosti i robovske obaveze u despotskijim

80 Ibid.

81 Ibid., 260.

82 Pavlović, Flogiston, 42.

83 Pavlović, Đavolji film, 358. 
društvenim formama no što su ranije bile. Jer, pored ostalih restrikcija, ukinute su i nekadašnje individualne slobode.

$\mathrm{U}$ predrevolucionarnim društvenim formacijama rob se barem mogao da nada da će, zahvaljujući sreći i ličnim sposobnostima, jednog dana napustiti mnoštvo izrabljivanih i obreti se u carstvu povlašćene svemoćne manjine. U postrevolucionarnom društvu pripadnik mnoštva napušta krdo robova samo ako ga obezličena vladajuća kasta hoće da primi u svoje redove po cenu odricanja od bilo kakvog duhovnog individualizma.

U postrevolucionarnom društvu svi su porobljeni: i oni koji nemaju i oni koji imaju." ${ }^{4}$

Ovaj kontrarevolucionarni impuls u Pavlovićevom svjetonazoru nešto je poput javne tajne za postjugoslavensku kritičku teoriju koja pokušava aproprirati reditelja u sklopu reaproprijacije "crnog vala" općenito. ${ }^{85}$ Gledano iz perspektive postjugoslavenske filmološke ljevice, kad je Pavlović u pitanju, usudio bih se reći: u sad već više od deset godina obnovljenog teorijskog $\mathrm{i}$ historičarskog interesa za novi jugoslavenski film, nismo se baš proslavili.

Od svih njegovih filmova najviše ushićenja i čitanja potaknuo je Kad budem mrtav i beo (1968), što je posve simptomatično, znamo li da je atipičan za Pavlovića u mjeri u kojoj Džimi Barka, glavni lik filma, nije posebno reprezentativan za protagoniste njegovih filmova $i$ proze. ${ }^{86}$ Borisu Budenu dugujemo lucidno čitanje da se "Džimi Barka našao oči u oči s kapitalističkom istinom reformiranog jugoslavenskog socijalizma" ${ }^{87}$ Gal Kirn je na istom tragu razradio tezu o Pavloviću kao kritičaru proturječja socijalističke industrijalizacije ${ }^{88}$ - i to bi manje-više bilo sve. Izvan tih okvira još uvijek se nismo stvarno pomakli

84 Pavlović, Flogiston, 124.

85 V. Gal Kirn, Dubravka Sekulić, i Žiga Testen (ur.) Surfing the Black: Yugoslav Black Wave Cinema and Its Transgressive Moments, 2012.

86 V. Pavle Levi, Disintegration in Frames: Aesthetics and Ideology in the Yugoslav and Post-Yugoslav Cinema, 2007: 36-37.

87 Boris Buden, Želimir Žilnik, kuda.org i ostali, Uvod u prošlost, 2013., 200-201. Vidi i Boris Buden, "Behind the Velvet Curtain. Remembering Dušan Makavejev's W.R.: Mysteries of the Organism”, Afterall 18, 2008.

88 Gal Kirn, “Živojin Pavlović kot kritik protislovij socialistične industrializacije: Nekaj notic ob gledanju filma Ko bom mrtav in bel", u: Prekletstvo iskanja resnice: Filmska ustvarjalnost in teorija Živojina Pavlovića, ur. Andrej Šprah, 23-34. 
ni kada je u pitanju Kad budem mrtav i beo, a, uz odveć rijetke iznimke, još manje kad je u pitanju recepcija ostatka Pavlovićevog djela. Pomak je nužan tim prije što navedena čitanja, koliko god bila dragocjena, uvode limit ekonomskog reducirajući Pavlovića - i "crni val" općenito - na reakciju na probleme jugoslavenskog privrednog razvoja (uvođenje tržišne ekonomije, postindustrijski način proizvodnje, itd.).

Ukratko, ta čitanja u Pavloviću vide dragocjenog suborca na ljevici (ili barem njezina suputnika) u današnjim ideološkim sukobima. Sjajnu ilustraciju te perspektive nudi Prekletstvo iskanja resnice: Filmska ustvarjalnost in teorija Živojina Pavlovića [Prokletstvo traženja istine: Filmsko stvaralaštvo i teorija Živojina Pavlovića] (2012), zbornik koji je uredio Andrej Šprah i u kojem čak ni prilog jednog Nebojše Pajkića ne može dovesti u pitanje činjenicu da je danas zapravo još jedino ljevici istinski stalo do Pavlovića. U zborniku, vrhunsku ljevičarsku fantaziju o Pavloviću in nuce artikulira Jurij Meden. Nakon što pobroji teme koje je Pavlović problematizirao u socijalizmu, Meden emfatički poantira: "Danas bi [Pavlović], u duhu svog revolucionarnog poslanstva i mogućnosti detektiranja društvenih čvorova, suočen s nefotogeničnošću financijskih tržišta, možda pružio prave rafale". ${ }^{9}$

Nakon svih citata Pavlovića na prethodnim stranicama, suvišno je eksplicirati zašto sam skeptičan prema ovoj pretpostavci. Pavlović nije Žilnik, autor kojeg postjugoslavenska kritička ljevica nije ni morala aproprirati—jednostavno se našla s njim na istoj stanici, jer Žilnik nikad nije ni krio da mu je srce na lijevoj strani. ${ }^{90}$ Pavlović nije ni Makavejev, čija glavna junakinja, nakon što je ubije "pravi crveni fašista",

89 Jurij Meden, "Pamflet o revolucionarnem naturalizmu Živojina Pavlovića”, u: Šprah, Prekletstvo iskanja resnice, 20: “Dandanes bi, v duhu svojega revolucionarnega poslanstva in zmožnosti detekcij družbenih vozlov, soočen s nefotogeničnostjo finančnih trgov, mogoče prožil prave rafale."

90 Podsjetimo da su ideološke razlike između njih utjecale na nepomirljivost njihovih estetika. Iako je u javnosti strateški podržavao Žilnika, Pavlović ipak nije cijenio njegov rad: "Želimir Žilnik: Rani radovi. Još onda, kad je napravljen, film nije valjao. A danas ne može da se gleda”, piše u dnevniku 20. ožujka 199o. (Dnevnik: Diarium II, 1990-1991, 40.) Žilniku dugujemo i anegdotu o zatvorenoj, pretpremijernoj projekciji Ranih radova: "Both Makavejev and Pavlović were stone-faced. They were saying, 'What have you made? This doesn't look like our direct legacy'. Pavlović even said, 'Ah Želimir, that is a cul de sac. Where is the man's passion, his sexual energy?'”. U: Kirn, Sekulić i Testen, Surfing the Black, 2012: 99. 
priznaje: "Drugovi, ja se ni sada ne stidim svoje komunističke prošlosti!" Pavlović je netko tko na tvrdnju "Bili ste komunista” — još jedan šlagvort sugovornice Milanović-Zeković u Ludilu u ogledalu —odgovara: "Bio sam. Komunizam je surogat potrebe za religijom. Za sve crkve smatram da u životnoj praksi imaju negativno dejstvo". ${ }^{1}$

Kritička postjugoslavenska ljevica dovoljno je hvalila Pavlovića-revolucionara koji razotkriva mrtvouzice jugoslavenskog socijalizma. Krajnji je trenutak da se pozabavimo i njegovim vlastitim mrtvouzicama od kojih su najproblematičnije upravo one koje razotkrivaju njegov depolitizirajući zazor spram modernosti — odnosno, one koje ga stavljaju na stranu kontrarevolucije. Bio bi to prvi istinski korak u njegovoj današnjoj "reaproprijaciji”, odnosno, u reaprorijaciji određenih segmenata njegovog djela. Zato je krajnje vrijeme da postjugoslavenska kritička ljevica nakon fascinacije “jebivjetrom” Džimijem Barkom otkrije i razočaranog revolucionara i djevca Ivu Vranu. "I vi ste mi neka revolucija!” - posljednje su riječi tog protagonista Zasjede (1969), filma koji i do danas ostaje "čudo neviđeno" Pavlovićevog opusa. Nastavimo li ignorirati Pavlovićeve mrtvouzice, Vranine zajedljive riječi mogle bi nam se obiti o glavu, samo u pervertiranom, suvremenijem obliku: "I vi ste mi neka kritika!"

91 Pavlović, Ludilo u ogledalu, 48. 


\section{LITERATURA}

Buden, Boris. "Behind the Velvet Curtain. Remembering Dušan Makavejev's W.R.: Mysteries of the Organism.” Afterall 18 (bez paginacije), 2008. http:// www.afterall.org/journal/issue.18/behind.velvet.curtain.remembering.dusan.makavejevs.

Buden, Boris, Želimir Žilnik, kuda.org i ostali. Uvod u prošlost. Novi Sad: Centar za nove medije_kuda.org, 2013.

Dimitrijević, Branislav. "Sufražetkinje, radodajke i lažne trudnice: Žene u filmu Kad budem mrtav i beo." U: "Kad budem mrtav i beo”-film Živojina Pavlovića, ur. Branislav Dimitrijević et al., 1-17. Beograd: Institut za film \& Filmograf, 1997. Ignjatović, Srba. "Čari atipične proze: Flogiston i Belina sutra Živojina Pavlovića” (pogovor). U: Pavlović, Flogiston, 168-181.

Kirn, Gal. "Živojin Pavlović kot kritik protislovij socialistične industrializacije: Nekaj notic ob gledanju filma Ko bom mrtav in bel.” U: Šprah, Prekletstvo iskanja resnice, $23-34$.

Kirn, Gal, Dubravka Sekulić, i Žiga Testen (ur.). Surfing the Black: Yugoslav Black Wave Cinema and Its Transgressive Moments. Maastricht: Jan van Eyck Academie, 2012.

Kovač, Mirko. "Kao svinje u blatu." Sarajevske sveske, br. 13 (2006): 456-473.

Levi, Pavle. Disintegration in Frames: Aesthetics and Ideology in the Yugoslav and Post-Yugoslav Cinema. Stanford: Stanford University Press, 2007.

Meden, Jurij. "Pamflet o revolucionarnem naturalizmu Živojina Pavlovića." U: Šprah, Prekletstvo iskanja resnice, 15-21.

Pajkić, Nebojša (ur.). Jahač na lokomotivi: Razgovori sa Živojinom Pavlovićem. Beograd: Studentski kulturni centar, 2001.

Pavlović, Živojin. Flogiston. Beograd: Književne novine, 1989.

Pavlović, Živojin. Ispljuvak pun krvi. Beograd: Izdavački atelje Dereta, 1990.

Pavlović, Živojin. Đavolji film: Ogledi i razgovori, drugo izdanje. Beograd: Institut za film, 1996.

Pavlović, Živojin. Dnevnik: Diarium II, 1990-1991. Novi Sad \& Beograd: Prometej \& Kwit Podium, 1999.

Pavlović, Živojin. Planeta filma: Sećanja. Beograd: Zepter Book World, 2002.

Pavlović, Živojin i Dušanka Milanović-Zeković. Ludilo u ogledalu: Razgovori o civilizacijama, o religijama, o čoveku, o životu i smrti, o mržnji, o ljubavi. Beograd: Srpska književna zadruga, 1992.

Šprah, Andrej (ur.). Prekletstvo iskanja resnice: Filmska ustvarjalnost in teorija Živojina Pavlovića. Ljubljana: Slovenska kinoteka, 2012. 